\title{
A Sarbanes-Oxley Act como instrumento de valores éticos, socioeconômicos e ambientais na governança corporativa: seus impactos no Brasil
}

\author{
Charlene Maria C. de Ávila Plaza \\ Nivaldo dos Santos ${ }^{2}$ \\ Maria Cristina V. B. Tarrega ${ }^{3}$
}

\section{Resumo}

O presente artigo visa, como objetivos, discorrer sobre os impactos da Lei Sarbanes-Oxley nas esferas empresariais e a sua possível democratização nos mercados, partindo de análises do processo de globalização e seus desdobramentos na tentativa de consolidação dos movimentos e projetos globais para que se estabeleçam caminhos que conduzam as empresas a uma maior sustentabilidade nos âmbitos socioeconômicos e ambientais, baseados nos princípios da governança corporativa. A governança corporativa é justificada e defendida tanto pelas empresas quanto pela sociedade e pelo Estado como fenômeno que abarca o reconhecimento da sua necessidade para a sobrevivência e perenidade de uma empresa no cenário internacional, por meio da utilização de melhores práticas de gestão e profissionalização. $\mathrm{O}$ mercado percebe a governança como instrumentos para a valorização de seus investimentos e as empresas, por sua vez, tornam-se mais atraentes perante os investidores a partir da conscientização dos princípios de transparência e eqüidade. Atualmente, para as empresas, a questão da governança corporativa abarca muito mais do que a justificação de sua criação, motivada pelos escândalos corpo-

\footnotetext{
${ }^{1}$ Mestre em Direito. Professora da Universidade Paulista UNIP-GO. Pesquisadora do Núcleo de Patentes e Transferência de Tecnologia - GO. Advogada Associada dos Escritórios CARRARO-GO. E.mail: charlene_plaza@hotmail.com.

${ }^{2}$ Doutor em Direito. Professor UFG/UCG. Coordenador Geral do Núcleo de Patentes e Transferência de Tecnologia-NUPATTE-GO. Coordenador do Programa de Mestrado em Direito, Relações Internacionais e Desenvolvimento-UCG-GO. E.mail: nivaldo@ucg.br.

${ }^{3}$ Doutora em Direito. Professora da UFG-GO e da Universidade Católica de Goiás-Goiânia. E.mail: mcvidotte@uol.com.br. Fomento: CNPq, FAPEG, FUNADESP, FUNAPE.
} 
rativos internacionais, abrangendo um contexto maior para aquelas que se preocupam em obter sucesso diante dos mercados internacionais, para divulgar o bom nome empresarial e, por conseqüência, valorizar seus papéis no mercado de ações.

Palavras-chave: Governança corporativa. Globalização. Transparência. Eqüidade. Mercado de ações.

\section{Introdução}

Governança corporativa, expressão originária do inglês corporate governance, pertencente ao Direito Consuetudinário dos países anglo-saxônicos, foi importada como subproduto da globalização, ao inserir as empresas nas melhores práticas corporativas nos âmbitos socioeconômicos, ambientais e éticos baseados nos princípios de transparência, equidade, obediência às leis e senso de justiça.

Atualmente, a governança corporativa não se refere apenas a um conjunto de princípios que propõem a regular as organizações das Sociedades Anônimas, mas também a um sistema que integra as sociedades empresariais em geral, dado o grau de importância que as empresas estão considerando para a inserção no comércio internacional.

Mas a idéia que impera sobre a universalização da responsabilidade corporativa necessita de melhores reflexões sob a ótica de mercado, pois, mesmo que ela seja um mecanismo global, não se restringe a unificá-lo porque não atua da mesma forma na economia, pois os padrões transnacionais existentes nesse modelo nem sempre se convergem devido às divergências e distinções entre os mercados e a maneira de sua inserção nas empresas de cada país.

Na verdade, o efeito da globalização nos países e nas empresas encoraja a serem diferentes, a procurarem uma forma distinta de reduzir a competição internacional ao invés de convergirem para o melhor modelo. Talvez não seja tão simples adaptar a governança corporativa para padronizar as regras em um sentido global, pois a globalização sugere muito mais para alavancar diferenças em um mundo que desenvolve em constante fluidez as fronteiras.

Em contrapartida, o efeito globalização é irreversível e a tendência será sempre de aproximação de um Direito Internacional na tentativa de harmonizar 
as normas para que sejam supranacionais, uma vez que nem o dinheiro e nem a ética possuem pátria e a governança corporativa, através de seus princípios, é uma opção segura entre os mercados e as empresas, sejam em âmbitos regional, nacional ou global.

Desenvolver a governança corporativa necessita muito mais do que a visão teórica de mercados; exige a prática de transposição cultural das empresas para que venham a minimizar as assimetrias existentes sobre as informações entre seus diversos agentes envolvidos na busca de maior transparência e credibilidade, com o objetivo de colher maiores investimentos e competitividade, baseados na ética e nas boas práticas de gestão configuradores do novo mercado que se descortina.

As crises e escândalos corporativos acontecidos nos últimos anos, principalmente nos mercados norte-americanos, despertaram as empresas para a relevância estratégica da governança corporativa como mecanismo de auxiliar na administração de seus riscos. Mas, para o bom estrategista que consegue extrair oportunidades em tempos de crise, as empresas, mesmo que a passos lentos, estão adequando-se a um novo modelo de gestão empresarial, baseadas nas melhores práticas de governança corporativa, relevando que não basta somente a existência de regras rígidas para o controle, como também a ética por parte de quem as administra.

Sob essa perspectiva, a Lei Sarbanes-Oxley, criada em 2002, promoveu várias mudanças fundamentadas nas melhores praticas de governança, agrupadas por quatro princípios: conformidade legal ou compliance; prestação responsável de contas ou accountability; transparência ou disclosure; e senso de justiça ou fairness, punindo severamente com sanções civis e penais as empresas e seus administradores que violarem suas normas.

A princípio, acreditava-se que a Lei Sarbanes-Oxley atingiria somente as empresas norte-americanas ou estrangeiras que negociassem nos mercados de valores dos Estados Unidos. No entanto, verificou-se que é muito interessante o efeito dessa lei para as empresas e para os investidores porque restaura o equilíbrio dos mercados por meio de mecanismos que asseguram a responsabilidade da alta administração de uma empresa no que concerne à confiabilidade da informação por ela fornecida. 
Por mais que a lei Sarbanes-Oxley seja protagonista de muitas controvérsias, desde as severas penas aplicadas a seus infratores até os altos custos para sua implantação, ela é um instrumento para coibir em grande parte as falcatruas perpetradas pelas corporações, por meio de seus administradores, em detrimento aos investidores minoritários.

Muitas empresas brasileiras que atuam nos mercados de valores americanos já aderiram às suas regras para a promoção da melhoria de seus controles internos com ética e transparência, elementos essenciais nos balanços empresariais com o fulcro de maior competitividade no cenário internacional.

Os objetivos do presente artigo visam, em um primeiro momento, discutir os efeitos da globalização nos mercados, na soberania dos países e nas empresas diante dos novos modelos de governança corporativa.

Discute-se em seguida, a responsabilidade corporativa e suas contradições éticas e sociais em busca de um consenso nos modelos de administrar os processos organizacionais de forma eficiente e sustentável aos moldes deste novo século que exige empresas cidadãs.

Logo após, analisa-se a Lei Sarbanes-Oxley como mecanismo regulador da gestão das melhores práticas corporativas, sua composição, as fraudes empresariais no âmbito global que impulsionou a sua criação, as tendências das empresas brasileiras baseadas nos modelos atuais, emergentes e de Novo Mercado de governança corporativa, encerrando o tópico e analisando comparativamente a Lei SarbanesOxley e a Lei Societária Brasileira.

Ao final, descreve-se o rol das empresas brasileiras operantes nas bolsas de valores norte-americanas, suas certificações e adesões na SOX (Sarbanes-Oxley), mencionam-se as empresas que participam dos níveis I, II e Novo Mercado na BOVESPA e conclui discorrendo sobre os Índices de governanças corporativos lançados em 2005 por essa Bolsa.

Para maior compreensão e desenvolvimento desta pesquisa, procurou-se realizar, com relação aos tópicos elencados, um estudo comparativo mediante pesquisa bibliográfica e documental, partindo de uma perspectiva analítica entre a Lei Sarbanes-Oxley e a legislação societária nacional. 
A abordagem metodológica consiste, essencialmente, na exposição analítica e comparativa do pensamento basilar de autores de diferentes ideologias que tratam, de maneira sistematizada, a questão das melhores práticas de governança corporativa.

Buscar-se-á, em argumentações teóricas, a evolução de dados que apontam evidências empíricas e os elementos que permitem deduzir acerca da questão.

Como referencial teórico, a pesquisa será originada de estudos realizados no âmbito do pensamento administrativo neoclássico, bem como nos estudos das principais leis societárias. Essas duas vertentes - a corrente neoclássica e o Direito - pautam por elaborar indicadores de sustentabilidade coorporativa. Será realizada revisão bibliográfica a partir de material já publicado, constituído principalmente de livros e revistas especializadas no assunto e outros meios disponíveis como intuito de avaliar criticamente o quadro teórico de referência, esperando oferecer contribuições originais.

\section{A sustentabilidade do pós-capitalismo no século XXI e a gover- nança corporativa mundial}

A globalização, muito embora não seja um fenômeno recente, é uma realidade fática que traz consigo crescentes assimetrias e descompassos entre nações como forma de aprofundar a característica estrutural do sistema capitalista mundial.

Crescentes assimetrias e descompassos, porque a globalização em si não é um fenômeno único; há a existência de diversas globalizações que avançam em velocidades díspares, afetando os conceitos de soberania e democracia entre as nações, gerando cada vez mais a diminuição da influência dos governos nacionais.

Nesse diapasão, a globalização apresenta-se como fenômeno de perspectivas distintas tanto na história e na sociedade quanto na economia e na cultura, por vezes, gerando complexas interpretações dialéticas entre o que é regional global e local, ou mesmo o que seja de responsabilidade pública ou privada.

Como fenômeno de abertura das economias nacionais, a globalização não resulta de uma mundialização homogeneizada, pois escolhe alguns lugares, certas atividades, determinados setores e alguns grupos ou segmentos sociais para serem mundializados. 
De acordo com Moreira ${ }^{4}$, "enquanto muitos lugares e grupos de pessoas globalizam, outros, às vezes bem próximos, ficam excluídas do processo", gerando a heterogeneidade do espaço mundial com relação à lucratividade laboral e as fortes concentrações de riqueza, fazendo com que cresçam as desigualdades sociais e econômicas entre os países.

Paradoxalmente ao aforismo predominante, "pense globalmente, aja localmente", hoje, a possibilidade concreta da nova ordem mundial faz com que os povos tenham condições de governar por meio de instituições internacionais em vez de fazê-lo em âmbito exclusivamente nacional.

Desse modo, emerge a globalização como superação das fronteiras, das barreiras locais e nacionais sob vários contextos, desde o mundo das finanças, nas relações de poder por meio das tecnologias e das revoluções energéticas, bem como nas questões sociais, éticas, filosóficas e políticas, uma vez que as idéias do colonialismo e imperialismo não mais se sustentam moral e eticamente.

Atualmente, o mundo não é mais linear, os muros foram derrubados, desapareceram as fronteiras entre países, bens e serviços circulam livremente, espaço e tempo não são conceitos uniformes, universais, mensuráveis, o pêndulo (espaço-tempo) se tornou confuso.

$\mathrm{Na}$ era do ciberespaço, no ecossistema da Internet, povoam bilhões de idéias para a humanidade, trazendo uma nova economia pós-capitalista, isto é, as noções sobre espaço-tempo e fronteiras foram superadas, uma vez que não são mais possíveis de serem mensurados.

Nascem desse conceito, à emergência de se criarem novos espaços baseados nos valores, interesses, interações entre atores em âmbito global, à medida que as fronteiras reais e imaginárias desaparecem diante do novo modelo capitalista global.

Para Castell ${ }^{5}$, as relações entre os principais atores do cenário internacional contemporâneo se intensificam pelos avanços tecnológicos e sistemas de comu-

\footnotetext{
${ }^{4}$ MOREIRA, Igor. O processo de globalização e regionalização. Ciências e Letras, Porto Alegre, n. 19, p. 15, 1997.

${ }^{5}$ CASTELL, Manuel. O poder da identidade. São Paulo: Paz e Terra, 1999.
} 
nicação, produção e interação como forma de domínio comum, pois influenciam diretamente a disseminação e a desterritorialização de pessoas, de idéias e de relações.

A denominada desterritorialização manifesta-se tanto na esfera econômica, social como também na política e na cultural, abarcando corporações transnacionais, mercados monetários, grupos étnicos, lealdades ideológicas e movimentos políticos, sistemas de mercado, regulamentos e padrões internacionais, tratados multilaterais, fluxo de energia e tecnologia, transcendendo fronteiras e identidades territoriais específicas.

Altera-se a base de muitas interações globais significativas que, de acordo com Wakeman apud Ianni', "põe em causa a definição tradicional de Estado", transcende as correntes de pensamentos, idéias e posturas difundidas na sociedade de forma ampla por meio da informação, levando seus agentes a repensarem suas estratégias de atuação, bem como seu posicionamento frente ao mundo.

Por outro lado, há uma dualidade das percepções sobre o processo de globalização, suas tendências e implicações que, segundo Ianni ${ }^{7}$, se a idéia do globalismo remete a um movimento de homogeneização, dissolvendo diversidades e identidades incorporando à sociedade conotações universais, por outro, gera sentimentos contrários aos seus efeitos com disparidades sociais, desemprego estrutural, etnocentrismo, racismo e fundamentalismo configuradores de intolerância e preconceito.

Um dos aspectos mais relevantes da nova estrutura pós-capitalista do século XXI é o surgimento de novos modelos de empresas, como ONGs (Organizações não Governamentais), preocupadas com a governança corporativa ${ }^{8}$, com o desenvolvimento participativo, não só em termos econômicos, mas também voltadas ao progresso social, ao desenvolvimento humano intra e extra empresas, aos desafios ambientais com as crescentes mudanças climáticas, aos

\footnotetext{
${ }^{6}$ IANNI, Octavio. A era do globalismo. 9. ed. Rio de Janeiro: Civilização Brasileira, 2007. p. 95. ${ }^{7}$ Ibidem.

${ }^{8}$ Denomina-se governança corporativa o papel que os Conselhos de Administração passaram a exercer para melhorar o ganho dos acionistas e arbitrar os conflitos existentes entre os mesmos, administradores, auditores externos, minoritários, conselhos fiscais (no Brasil) e os stakeholders: empregados, credores, fornecedores, clientes.
} 
direitos das minorias e à implementação das inovações tecnológicas como suportes do tripé - econômico, social e ambiental.

No contexto socioeconômico, a inovação tecnológica é de relevante importância para as empresas que desejam manter o grau de competitividade no mercado e a qualidade dos produtos, porque precisam atender simultaneamente as demandas por eficiência, qualidade e flexibilidade, otimizando cada vez mais a necessidade de investimento em P\&D (Pesquisa e Desenvolvimento) com o objetivo de dominar o estado da arte das novas tecnologias.

Na seara ambiental, as empresas preocupadas com as provas inequívocas do aquecimento global e a elevação dos níveis de gases de efeito estufa estimulam as práticas sustentáveis de forma a melhorar o desempenho da eficiência energética, capaz de reduzir a dependência gradual das energias fósseis.

As empresas que focam nesses objetivos colaboram com o presente e um futuro com menos poluição e mais harmonia com a natureza e, logicamente, o cultivo do bom nome empresarial mediante o mercado internacional que não tolera empresas insustentáveis ambientalmente.

Um caso de gestão bem sucedida nos remete ao Banco Real ABN AMRO que em sua estratégia de promover o crédito para empresas ecologicamente sustentáveis, restringe as concessões por meio de equipes que contabilizam os riscos socioambientais de empresas que não se preocupam com a gestão socioambiental.

A equipe segue os padrões formulados pelos princípios do Equador, estipulados pelo Banco Mundial em 2003 e, desde 2002, mais de 49 empresas tiveram seus créditos indeferidos por não atuarem de acordo com os padrões socioambientais, ofertando ao banco um caráter mais transparente e digno de maior credibilidade no cenário nacional e internacional. ${ }^{9}$

A verdadeira governança corporativa contemporânea também abarca novas concepções sobre a organização burocrática do capital humano fazendo cair por terra o pensamento mecanicista defendidos por Max Weber e Frederick Taylor

\footnotetext{
${ }^{9}$ BERNA, Vilmar; URBAN, Teresa. Os heróis do verde. Época, São Paulo, Edição Especial, p. 51-57, out. 2006.
} 
que rotinizavam a divisão de tarefas, regras, regulamentos e cargos hierárquicos como verdadeiro "Leito de Procusto" ${ }^{10 "}$ que, por muito tempo, corroeu o espírito humano e a capacidade de ação espontânea inerentes ao ser humano - a capacidade criativa.

Rosenau ${ }^{11}$ nos diz que a governança configura um conceito mais amplo do que o conceito de governo, pois transcende as ações do Estado no cenário mundial, envolvendo atores transnacionais como instituições internacionais, empresas, organizações não governamentais e a própria sociedade civil.

Muito embora criada no início da década de 90 nos países desenvolvidos, (EUA E Grã-Bretanha), para definir as regras que regem o relacionamento dentro de uma companhia dos interesses de acionistas controladores, dos minoritários e administradores, a idéia de governança corporativa é antiga e tem sua origem nos chamados problemas de agência ${ }^{12}$, que nascem com a diluição do domínio das corporações.

No Brasil, o Instituto Brasileiro de Governança Corporativa - IBGC ${ }^{13}$ formula a seguinte definição:

\footnotetext{
${ }^{10}$ Passagem mitológica aplicada às situações em que a utilização da força atropela as diferenças existentes entre os indivíduos, ou desrespeita as circunstancias especiais que caracterizam os sistemas de vida adotados pelas pessoas. No Direito, a figura mitológica costuma ser invocada como metáfora de certos aspectos da atividade jurídica, considerando semelhantes à Procusto aqueles que tentam enquadrar, de modo inadequado, determinada realidade em um conceito que ela não se ajusta, equívoco que sempre resulta em conseqüências negativas. DANNEMANN, Fernando Kiyzinger. Leito de Procusto: expressões populares. Disponível: <www.fernandodannemann.recantodasletras.com.br/ visualizar. php?=135407>. Acesso em: 10 maio 2008.

${ }^{11}$ ROSENAU, James; CZEMPIEL, Ernest-Otto. Governança sem governo: ordem e transformação na política mundial. Brasília: Universidade de Brasília, 2000.

${ }^{12} \mathrm{O}$ empreendedor, ou gestor capta recursos dos investidores para aplicá-los em projetos rentáveis ou para se apropriar destes recursos. Os investidores por sua vez, necessitam de gestores qualificados para fazer com que os recursos acumulados possam ser aplicados em projetos rentáveis. Como normalmente os empreendedores ou gestores, necessitam do capital dos investidores para concretização de seus objetivos, pois, ou não dispõem de recursos suficientes ou desejam diversificar seus investimentos, e, os investimentos, e, os investidores têm consciência da possibilidade de apropriação de seus recursos pelos gestores, problema da agencia que se coloca é: como garantir aos investidores que seus recursos sejam aplicados atendendo aos seus interesses? SHLEIFER, Andrei; VISHNY, Robert. A survey of corporate governance. Journal of Finance, v. 52, n. 2, p. 737-738, 1997

${ }^{13}$ INSTITUTO BRASILEIRO DE GOVERNANÇA CORPORATIVA (IBGC). Código das melhores práticas de governança corporativa. 2004. Disponível em: <http://www.ibgc.org. br>. Acesso em: 10 maio 2008
} 
Governança corporativa é o sistema que assegura aos sócios proprietários o governo estratégico da empresa e a efetiva monitoração da diretoria executiva. A relação entre propriedade e gestão se dá através do conselho de administração, a auditoria independente e o conselho fiscal, instrumentos fundamentais para o exercício do controle. A boa governança assegura aos sócios eqüidade, transparência, responsabilidade pelos resultados (accountability) e obediência às leis do país (compliance). No passado recente, nas empresas privadas e familiares, os acionistas eram gestores, confundindo em sua pessoa propriedade e gestão. Com a profissionalização, a privatização, a globalização e o afastamento das famílias, a governança corporativa colocou o Conselho entre a Propriedade e Gestão.

Na governança corporativa, há uma complementaridade dos diversos setores com a finalidade de alcançar a sustentabilidade e sanar as deficiências e desigualdades geradas pela globalização. Dessa maneira, o Mercado, Estado e Terceiro Setor se complementam, sendo que, em um primeiro momento, a governança global condiciona-se ao mercado e a seus instrumentos capazes de produzir o crescimento econômico e que, por sua vez, dependem da ação coordenada da sociedade civil e entidades estatais para que consiga atingir sua atuação e influenciar o todo.

Seus princípios se baseiam justamente nos atendimentos às exigências específicas de diferentes áreas de ação, com o desenvolvimento de parcerias, redes de instituições e processos, somatização de informações e conhecimentos com o escopo de desenvolver políticas e práticas conjuntas para o bem comum.

No entanto, o mercado, concebido inicialmente como condutor de melhoria social, não conseguiu concretizar a qualidade da condição humana, passando a se concentrar na busca do lucro, "atropelando certos princípios em que o fim justificaria os meios". ${ }^{14}$ Em socorro, surge a figura do Estado como provedor do bem estar social que também não logrou êxito, sendo que a figura da empresa passou a exercer um papel diferenciador, uma vez que o Estado demonstrou ser ineficaz e insolvente quanto aos serviços, recursos e infra-estrutura que atendessem os reais interesses sociais, bem como em manter as necessidades básicas dos cidadãos.

\footnotetext{
${ }^{14}$ DEJOURS, Christophe. A banalização da injustiça social. Rio de Janeiro: FGV, 2001. p. 14
} 
A sociedade, em contrapartida, vislumbrou as empresas como as grandes portadoras e geradoras de riquezas materiais e causas sociais, principalmente no final do século XX. Dessa nova consciência, surge o fenômeno da responsabilidade corporativa que influenciaria diretamente não só como produtora de bens e serviços, como também assumiria a participação nas esferas sociais como propagadoras e garantidoras do bem-comum, abarcando para si questões antes designadas a outros sistemas organizacionais, que se tornariam periféricos.

O Instituto Ethos ${ }^{15}$ define responsabilidade social corporativa como sendo:

Uma forma de conduzir os negócios da empresa de tal maneira que a torna parceira e co-responsável pelo desenvolvimento social. A empresa socialmente responsável é aquela que possui capacidade de ouvir os interesses das diferentes partes (acionistas, funcionários, prestadores de serviços, fornecedores, consumidores, comunidade, governo e meio-ambiente) e conseguir incorporá-los no planejamento de suas atividades, buscando atender às demandas de todos e não apenas dos acionistas ou proprietários.

Fica evidente que a empresa, para exercer a governança corporativa, não deverá ficar adstrita aos aspectos econômicos, mas aliá-los às questões de gestão de ética para todos os stakeholders e aos apelos da sociedade.

Essa definição, muito embora incômoda pela crença arraigada que as empresas deverão exercer os seus fundamentos principais que é a obtenção de lucros, passa a enfrentar o verdadeiro paradigma econômico do século XXI, ou seja, a convergência do próprio desenvolvimento econômico com o desenvolvimento das potencialidades humanas e a sustentabilidade ambiental para atingir e garantir o bem de toda humanidade.

\section{A responsabilidade corporativa à procura de um consenso: suas contradições éticas e socioambientais}

O grande desafio da governança corporativa reside no fato da pluralidade de agentes e de ações que, às vezes, não convergem para os mesmos fins sob a égide da globalização.

${ }^{15}$ INSTITUTO ETHOS. Responsabilidade social corporativa. Disponível em: <http://www. ethos.org.br>. Acesso em: 10 maio 2008. 
Sob essa ótica, há a necessidade de desenvolver estratégias que aliem setores da sociedade nos mais variados níveis, complementando-se com o intuito de sanar deficiências e desigualdades próprias da nova "era globalizada" em busca de uma economia de mercado participativa e de um desenvolvimento integral em busca da equidade e bem-estar social no pós-capitalismo que pretende um dia ser sustentável.

Barbosa ${ }^{16}$ nos diz que as empresas estão provocando na sociedade uma revolução silenciosa, tornando-se comunidades auto-suficientes e totais e, por conseqüência, transformando a vida humana em seu aspecto mais íntimo, impactando não somente a vida de seus funcionários, mas de toda comunidade. "Nenhum dos domínios da vida lhe é, a priori, proibido", pois ela se considera com "responsabilidade ilimitada". ${ }^{17}$

Assim, o que se verifica é a passagem do capitalismo, no qual a empresa cumpria papel central, mas não dominante, a um neocapitalismo que as transforma em instituição das instituições, tranvestindo-se de determinada ética para suprir falha de outras instituições, tornando-se empresa cidadã com a inserção dos indivíduos no interior do corpo social, abarcando o desenvolvimento econômico da nação como também o psicológico e o cívico.

Essa postura de empresa "ética e cidadã, guardiã da moral" é a forma de manter um mínimo de confiabilidade interna para que ela possa atuar e auferir lucros, crescer, expandir e sobreviver no novo contexto global. ${ }^{18}$

Questionamentos surgem sobre a questão da "ética e uma ação que não lhe corresponde" no âmbito das organizações, e até que ponto as ações propostas pela responsabilidade social corporativa correspondem à prática organizacional. ${ }^{19}$

\footnotetext{
${ }^{16}$ BARBOSA, L. O centro do universo. Exame, São Paulo, ano 35, n. 7, p. 107-110, 2001.

${ }^{17}$ ENRIQUEZ, E. Os desafios éticos nas organizações modernas. Revista de Administração de Empresas, São Paulo, v. 37, n. 2, p. 10, abr./jun. 1997.

${ }^{18}$ FREITAS, M. E. de. A questão do imaginário e a fronteira entre cultura organizacional e a psicanálise. In: MOTTA, F. C. P.; FREITAS, M. E. de. Vida psíquica e organização. São Paulo: FGV, 2000.

${ }^{19}$ FARIA, J. H.; MENEGHETTI, F. K. Discursos organizacionais. In: ENANPAD, 25., 2001, Campinas, Anais do XXV Anpad. São Paulo: Anpad, 2001. p. 1.
} 
A lógica econômica preponderante no ambiente organizacional, representada pela ideologia do realismo econômico, faz o cinismo passar por forças de caráter, por determinação e por um elevado senso de responsabilidades coletivas, em um cenário em que as vítimas na guerra econômica são inevitáveis e em que todos são convocados a integrarem o sistema de "banalização das injustiças sociais". ${ }^{20}$

As distâncias entre o mundo do trabalho e a proposta da responsabilidade social corporativa apresentam suas variantes que nem sempre mostram a realidade organizacional e, por muitas vezes, ainda se apresentam regadas sob a égide da pressão interna da empresa no que diz respeito aos trabalhadores.

Nesse sentido, do não reconhecimento de suas competências, o medo do desemprego, as pressões por altos índices de produtividade e o rígido controle gerencial exigem novas adoções de tecnologias físicas de gestão, consistentes em formas mais sutis e efetivas para melhor interação entre trabalhadores e administradores.

De fato, como preceitua Faria ${ }^{21}$ :

O ideólogo organizacional deseja construir princípios da moral, do direito, da ética, da democracia e do comportamento que devem ser respeitados na organização, não baseado na realidade das condições sociais que lhe dão suporte, mas partindo de um conceito já previamente formulado no interior de seu grupo, sua seita ou corporação, sobre o que é moral, direito, ética, democracia e comportamento. [...] Neste sentido, o conceito de princípios éticos moral e democráticos pode ser o que for mais conveniente aos seus elaboradores e usuários ocasionais.

Entre a teoria e a ação de um novo modelo organizacional de práticas mais éticas e democráticas, há ainda um hiato que precisa ser reformulado para que essas não fiquem subordinadas à mera competitividade de mercado em detrimento da desvalorização humana, mesmo porque o capital humano ainda é, e sempre será, fonte inesgotável de transformação criativa no ambiente empresarial.

${ }^{20}$ DEJOURS apud SOARES, Gianna de Paula. Responsabilidade social corporativa: por uma boa causa? Revista Era Eletrônica: Fórum Estudos Críticos em Administração, São Paulo, p. 11, 2004.

${ }^{21}$ FARIA, J. H.; MENEGHETTI, F. K. Discursos organizacionais. In: ENANPAD, 25., 2001, Campinas, Anais do XXV Anpad. São Paulo: Anpad, 2001. p. 1. 
Por outro lado, o discurso, até então dominante do setor empresarial no cenário internacional quanto às práticas sociais e ambientais das empresas e suas resistências quanto à minimização dos impactos por comprometer a lucratividade e competitividade, vem perdendo vertiginosamente o caráter de oposição empresarial ou mesmo a visão dicotômica entre o meio ambiente e a competitividade.

Com isso, as empresas começam a contabilizar os riscos sociais e ambientais para diminuir o grau de incertezas no mercado global, transcendendo os limites dos riscos financeiros e contemplando os riscos socioambientais, mesmo porque há uma maior conscientização de que as práticas que devastam o meio ambiente não causam impactos meramente locais, mas adquirem proporções planetárias.

Diante dessa perspectiva, há também um constante crescimento de organizações não governamentais e grupos comunitários que se destacam perante a sociedade como o Greenpeace, Sierra Club e outras que fazem inveja a empresas consolidadas como Microsoft, Monsanto, Nike, no que concerne às responsabilidades ambientais e sociais.

Nesse novo cenário de governança corporativa, há o nascimento de um modo totalmente vanguardista de administração nos processos de organização dentro das empresas cuja preocupação da eficiência no uso de recursos, na conservação de energias, na redução da poluição, nas inovações de marketing organizacionais e na maximização da qualidade em todos os níveis fizeram com que adotassem os "selos verdes" e as certificações ISOS (Organização Internacional de Padronização) 14000 e 14001 para se adequarem às práticas e políticas de gestão ambiental.

Adotando essas certificações, as empresas, além de melhorarem a imagem perante a sociedade, fazem com que em seu ambiente interno se desenvolva uma nova consciência, tanto das empresas como de seus funcionários, nos aspectos ambientais e na sua importância para o planeta. Exemplo claro dessa iniciativa é o caso da General Motors (GM) que exige de todos os seus fornecedores a obtenção da ISO 14001.

É importante salientar que, dessa concepção, poderão também surgir novos modelos de ISOS relativos à responsabilidade social e ao desenvolvimento sustentável, com excelentes benefícios tanto para as empresas como para a sociedade em geral. 
Todas essas mudanças que ocorrem na nova ordem mundial são devidas à necessidade de atitudes mais sustentáveis perante o planeta e pelos desdobramentos da globalização, originando, dessa forma, vários acordos e tratados internacionais que são implementados para a viabilidade e concretização dessas ações.

Dentre eles, destacam-se, principalmente a partir do início da década de 1990:

- O Programa das Nações Unidas para o Meio Ambiente;

- A Convenção de Viena-Montreal, Protocolo de Montreal Emenda de Londres para a proteção da camada de ozônio;

-O Global Environment Facility, organização financeira independente para projetos de sustentabilidade ambiental global;

-A Convenção de Basel sobre o comércio de lixo tóxico;

- O Acordo de Madri, visando à proteção da Antártida frente as fortes ofensivas de empresas transnacionais para exploração;

- As Convenções do Rio-92 e a Convenção de desenvolvimento sustentável da ONU-93 sobre mudanças climáticas e biodiversidade.

Esses mecanismos se fizeram necessários não somente para o tratamento de questões ambientais, mas para os relacionados á preocupação de buscar soluções que garantissem a melhoria social, as questões de ética e transparência nas relações de trabalho e empresas e para fomentar os princípios dos direitos humanos de modo convergente ao crescimento econômico em âmbito internacional.

Desse modo, as empresas iniciam um novo caminho para se adaptarem à realidade que se descortina, criando nova modelagem de seu papel socioambiental e, por conseguinte, deixando de representarem apenas negócios que visam lucros, mas um sistema vivo, com vários agentes e grupos de interesses capazes de transformar o ambiente em que convivem e atuam. 


\section{A Sarbanes-Oxley Act como instrumento de melhoria na go- vernança corporativa das empresas}

As fraudes financeiras perpetradas entre as décadas de 2001-2005 por muitas empresas ${ }^{22}$, como os casos das norte-americanas - Enron, Wordcom, Imclone, Arthur Andersen, Xérox, Bristol-Meyers Squibb, Merck, Tyco, Adelphia, e as européias - Royal Ahold, na Holanda; Altran Technologies, na França; Comroad, na Alemanha; Parmalat, na Itália e Élan, na Irlanda, conferiram ao Congresso norte-americano a edição da Lei Sarbanes-Oxley em 2002, na tentativa de resgatar maior transparência e credibilidade nas práticas de gestão e governança corporativa e, por sua vez, refrear a tradicional autoregulamentação dos mercados, baseadas na livre iniciativa.

Além disso, com o aumento das atividades bancárias internacionais ${ }^{23} \mathrm{e}$ o crescente uso de instrumentos financeiros derivativos (hedge) surgiu a necessidade da criação de ferramentas para gerenciamento de ativos e passivos, de forma a preservar a solidez dos sistemas financeiros nacionais e internacionais em busca de padrões e regras de transparência de informações.

\footnotetext{
${ }^{22}$ Além das empresas mencionadas acima, destacam-se também: AOL-provedor americano de internet que utilizou práticas contábeis "estranhas" para inflar suas receitas de 2000 a 2002 em US\$270,1 milhões, dentre os artifícios empregados foi contabilizar como receita sua venda de anúncios em nome da empresa de leilões virtuais eBAy. Duke Energy - inflando suas receitas em 1 US\$ bilhão, ao longo de três anos com negócios fictícios - como dois operadores comprando e vendendo contratos de energia entre si. Qwest-a numero 4 em telefonia local nos EUA anunciou estar sendo investigada por promotores públicos por descrição errônea de ativos no balanço. Global Crossing - investigação sobre a capacidade de cumprimento de contratos em longo prazo. Dunegy - fez projeto em que combinou com parceiros a elevação nos valores de contratos de compra de gás que inflaram artificialmente seus ativos. Peregrine Systems - durante três anos seguidos errou ao reportar seus ganhos nos balanços da companhia. Computer Associates - a SEC investiga o sistema de premiação, após Charles Wang, fundador, e mais dois executivos terem recebido US\$ 1 bilhão em ações, dias antes de lançarem um aviso de redução na projeção de lucros. Rite Aid-acusada de elevação artificial de lucros e de ter fraudado acionistas. Network Associates - investigada sob suspeita de ter alterado balanço.

${ }^{23}$ Algumas instituições bancárias que estão sendo processadas pela SEC: Merrill Lynch, Daniel Gordon, James Brown, JP Morgan, Daniel Ferguson, Credit Suisse First Boston, Citygroup Global Markets, Morgan Stanley, USB Waburg, Jack Grubman, entre outros. SEC- SECURITIES EXCHANGE COMMISSION. Litigation releases. Disponível em: $<$ www.sec.gov/litigation>. Acesso em: 19 maio 2008.
} 
Nas empresas norte-americanas acima mencionadas, houve a constatação da manipulação de dados e erros na apuração e divulgação ao mercado, assim:

- A Enron: empresa que atua no setor de energia, empregou artifícios excusos como mecanismos de fraude, denominados de contabilidade criativa e ausência de transparência com a confirmação da utilização de subsidiárias de propósito específico, não controladas ou consolidadas diretamente pela holding, que possuíam passivos significativos. ${ }^{24}$

- A Wordcom: que atua no ramo de telecomunicações a longa distancia, sendo a primeira operadora mundial em serviços da internet, manipulou resultados por intermédio da contabilização de despesas com ativo que fazia gerar lucros maiores ou omitir prejuízos. ${ }^{25}$

- A Imclone Systems: empresa farmacêutica, utilizou-se de informações privilegiadas na venda antecipada de ações que estavam em crescente valorização em função do desenvolvimento do remédio contra o câncer, cuja autorização para comércio ainda não fora concedida. ${ }^{26}$

- Arthur Andersen: tida como empresa modelo na área de auditoria, esteve envolvida com todas as implicações do escândalo Enron. Considera partícipe de um mega grupo conhecido no mercado como Big Five ${ }^{27}$ e considerada de renome, dado à sua eficiência e confiabilidade.

- Xérox: admitiu ter inflado seu faturamento em US\$1,9 bilhão, contabilizando de uma única vez vendas de equipamentos que seriam pagos em longo prazo. ${ }^{28}$

${ }^{24}$ HAMILTON, S. The enron collapse. [S.1.]: Internacional Institute for Management Development, 2003.

${ }^{25}$ KAPLAN, Robert S.; KIRON, David. Accounting fraud at wordcom. [S.1]: Harvard Business School, 2004.

${ }^{26}$ INSTITUTO BRASILEIRO DE GOVERNANÇA CORPORATIVA (IBGC). Código das melhores práticas de governança corporativa. 2004. Disponível em: <http://www.ibgc.org. br>. Acesso em: 10 maio 2008.

${ }^{27}$ Big five: Denominação usual dada pelo mercado às empresas Pricewatherhousecoopers, $a$ Deloitte Touche Tohmatsu, a Ernst \& Young e a KPMG.

${ }^{28}$ A Xérox concordou em 2002, em pagar multa de US\$ 10 milhões á SEC, a maior paga pela companhia, por ter informado erradamente o registro contábil das receitas. 
- Bristol-Myers Squibb: empresa farmacêutica que durante os exercícios de 2000 e 2001 concedeu descontos considerados abusivos, forneceu receitas adicionais de US\$ 1,5 bilhão sob o argumento de ser adiantamento de vendas ainda não realizadas.

- Merck: empresa farmacêutica, atuante nos segmentos de química e petroquímica, inflou suas receitas e despesas, levando o investidor a erro. Pagou multa a SEC e republicou seus balanços.

- Tyco: atuante no ramo de eletrônica, seguros de saúde, transferiu suas subsidiárias para paraísos fiscais, pagando multa a SEC de US\$ 50 milhões por prática de fraude contábil.

- Adelphia: sexta maior empresa de TV a cabo dos EUA, sonegou informações de suas dívidas aos acionistas, bem como foi constatado desvio de verbas da empresa para negócios particulares de seu fundador e presidente da companhia. Avaliados US\$ 60 bilhões de prejuízos para os acionistas.

- Parmalat: empresa italiana, manipulou seus relatórios contábeis, mascarando um grande esquema de fraudes em que o próprio controlador da empresa vinha desviando recursos. Com intuito de omitir sua precária situação financeira, informava que tinha direitos a receber, que não correspondiam à verdade. Em 2005, a empresa contava com uma dívida global de US\$ 900 milhões, sendo que, US\$ 150 milhões junto a seus fornecedores.

Foram estabelecidas, por essas razões, as empresas interessadas em manter ou ingressar no mercado de capitais norte-americano, um conjunto representativo de determinações, medidas punitivas, normas e regras em diferentes âmbitos e fronteiras, a fim de garantir que as informações econômicas e financeiras chegassem até os interessados de forma uniforme, transparente e coerente com a realidade.

Além de regular o mercado de capitais, a lei ultrapassa os limites da Bolsa de Valores, vez que passou a considerar a ética e a moral como primordiais para a gestão empresarial, preocupando-se com as responsabilidades do indivíduo para com a empresa, e desta para com ele. Regulamenta, ainda, assuntos pertinentes ao mundo dos negócios, adequação de salários e benefícios, condições salutares de trabalho e políticas pessoais não discrimina- 
tórias, vez que considera que as empresas são reflexos das condutas de seus indivíduos.

Por extensão, aplicam-se suas diretrizes às empresas estrangeiras que possuem valores mobiliários registrados na Securities and Exchange Commis$\operatorname{sion}^{29}$ (SEC), ampliando sua aplicação no mercado de capitais, inclusive as empresas brasileiras, suas matrizes e filiais que possuem ações nas bolsas de valores norte-americanas se sujeitaram ao império da Sarbanes-Oxley e suas regulamentações.

Há a responsabilidade das empresas e de seus gestores em repassarem informações corretas e demonstrações bem elaboradas a fim de que seja dada maior transparência nas transações, impondo a ética e a moral como fatores basilares e fundamentais para suas negociações no mercado de capitais.

Atualmente, há previsão de uma fiscalização mais rigorosa da lei antifraudes corporativas, principalmente com relação às instituições bancárias, devido às crises das hipotecas de baixa qualidade no mercado acionário, uma vez que o sistema de gestão de risco dessas instituições foi falho na aplicação dos empréstimos hipotecários.

Acontece que, desde sua implantação em 2002, a lei vem encontrando certas resistências entre países em conciliar os interesses desta às jurisdições internas, como o caso da Alemanha e Japão que consideram as proposições desse Ato, contrárias às suas legislações locais; por sua vez, o Brasil em sua lei societária não se deparou com conflitos maiores relativos aos dispositivos da Sarbanes-Oxley Act, como se verifica na tabela abaixo:

${ }^{29}$ Agência do governo norte-americano com autoridade legal para estabelecer os princípios contábeis. 


\section{Quadro comparativo dos requisitos de governança entre a SOX e a Legislação Societária Brasileira}

\begin{tabular}{|c|c|c|}
\hline Requisitos de Governança & $\begin{array}{c}\text { Lei } \\
\text { Sarbanes-Oxley }\end{array}$ & $\begin{array}{c}\text { Legislação Brasileira } \\
\text { (Lei 6.404/76 e alterações } \\
\text { posteriores) Lei 10.303/01 }\end{array}$ \\
\hline $\begin{array}{l}\text { Eleição e destituição de } \\
\text { auditores independentes }\end{array}$ & Comitê de Auditoria & Conselho de Administração \\
\hline $\begin{array}{l}\text { Atuação do comitê de } \\
\text { auditoria na companhia }\end{array}$ & Permanente & $\begin{array}{l}\text { O Conselho Fiscal não } \\
\text { é obrigatório, instalado } \\
\text { quando requerido por parte } \\
\text { dos acionistas. }\end{array}$ \\
\hline $\begin{array}{l}\text { Instrumentos de gestão: } \\
\text { avaliar as atividades } \\
\text { de auditorias interna e } \\
\text { independente, acompanhar } \\
\text { o processo de controle } \\
\text { interno e de divulgação, } \\
\text { assegurar o cumprimento } \\
\text { de obrigações legais } \\
\text { e regulamentares, } \\
\text { acompanhar e aperfeiçoar } \\
\text { a comunicação entre os } \\
\text { auditores e administradores. }\end{array}$ & Comitê de Auditoria & $\begin{array}{l}\text { O Conselho Fiscal é } \\
\text { um Colegiado com } \\
\text { competência para opinar } \\
\text { e fiscalizar os atos da } \\
\text { administração, sem a } \\
\text { necessária interação } \\
\text { direta com os auditores e } \\
\text { colaboradores. }\end{array}$ \\
\hline $\begin{array}{l}\text { Receber e tratar as } \\
\text { denúncias de fraudes e } \\
\text { atos ilícitos dentro da } \\
\text { companhia }\end{array}$ & Comitê de Auditoria & Não previsto \\
\hline $\begin{array}{l}\text { Membros do Colegiado } \\
\text { Fiscalizador }\end{array}$ & $\begin{array}{l}\text { Membros do Conselho de } \\
\text { Administração }\end{array}$ & $\begin{array}{l}\text { O Conselho Fiscal não } \\
\text { pode ser formado por } \\
\text { membros de órgãos de } \\
\text { administração, empregados } \\
\text { da companhia ou de } \\
\text { sociedade controlada ou } \\
\text { ainda do mesmo grupo. }\end{array}$ \\
\hline Indicação de especialista & $\begin{array}{l}\text { Composto por pelo menos } \\
\text { um especialista financeiro }\end{array}$ & $\begin{array}{l}\text { Deve ser composto por } \\
\text { pessoas naturais, residentes } \\
\text { no país e diplomadas em } \\
\text { nível superior. }\end{array}$ \\
\hline
\end{tabular}

Fonte: KPMG. Audit Committe Institute. SOX 301. [S.I.]: Conselho Fiscal ou Comitê de Auditoria, 2005. Tabela 1. 
A legislação Federal 'The U.S Public Company Accountability Reform and Investor Protection Act of 2002 "Sarbanes-Oxley Act-SOX possui 11 capítulos e 66 seções divididos em seus 1.107 artigos, definindo regras tanto para companhias estrangeiras quanto para as nacionais que possuam ações listadas na Bolsa de Valores de Nova Iorque.

\section{Composição da Lei Sarbanes-Oxley:}

\begin{tabular}{|l|}
\hline Capitulo I - Criação do Órgão de Supervisão do Trabalho dos Auditores Independentes \\
\hline Capitulo II - Independência do Auditor \\
\hline Capitulo III - Responsabilidade Corporativa \\
\hline Capitulo IV- Aumento do Nível de Divulgação de Informações Financeiras \\
\hline Capitulo V- Conflito de Interesses de Analistas \\
\hline Capitulo VI-Comissão de Recursos e Autoridade \\
\hline Capitulo VII-Estudos e Relatórios \\
\hline Capitulo VIII-Prestação de Contas das Empresas e Fraudes Criminais \\
\hline Capitulo IX-Aumento das Penalidades para Crimes de Colarinho Branco \\
\hline Capitulo X - Restituição de Impostos Corporativos \\
\hline Capitulo XI-Fraudes Corporativas e Prestação de Contas \\
\hline
\end{tabular}

Fonte: BORGERTH, Vânia Maria. SOX. Entendendo a Lei Sarbanes-Oxley. São Paulo: CENGAGE/Learning, 2007. p. 19. Tabela 2.

Trata-se de um documento obrigatório para as empresas que querem enquadrar-se na governança corporativa, delegando aos executivos, como premissas básicas, a tarefa de elaboração de um código de ética, inserindo todos os funcionários da empresa a um programa de educação ética integrado na boa gestão empresarial de todos os participantes da organização. Warner ${ }^{30}$ preceitua que:

The Sarbanes-Oxley Act of 2002, among other provisions, made CEO's and chief financial officer personally responsible for ensuring the accuracy of financial reposting. But balance sheets are only the beginning. The act also required the U.S Sentencing Commission to review program its 14 years old guidelines on what constitutes an "effective compliance and ethics program". The tougher guidelines, which went into effect Nov. 1, charge CEO's with promoting "an organizational cultures that encourager's ethical conduct.

${ }^{30}$ WARNER, J. Ethics for sale: in today's regulatiory climate, CEO's may have choice but to buy. Bunissess Publications, 2004. Disponível em: <http://findarticles.com/p/articles/ mi_m4070/is_203/ai_n8641866/2log=content;col1>. Acesso em: maio/2008. 
Possivelmente, algumas empresas brasileiras não se adequam às regras da Sarbanes-Oxley, deixando de emitir papéis no mercado americano (ADRs - American Depositary Receipts), devido aos altos custos de adequação, além de terem que transpor dois grandes desafios no que concerne a atender os artigos 404 e $301^{31}$ da respectiva Lei.

De acordo com pesquisa realizada pelas consultorias Mc Kinsey e KornFerry $^{32}$, denota-se uma maior adesão pelas empresas nacionais à prática de melhores responsabilidades corporativas, baseada em três modelos em curso no Brasil: o atual, o emergente e o de mercado, conforme tabelas 3, 4 e 5, abaixo:

\section{Tendências do modelo Atual de governança:}

\begin{tabular}{|l|}
\hline \multicolumn{1}{|c|}{ Modelo Atual } \\
\hline \multicolumn{1}{|c|}{ Estrutura de Propriedade } \\
\hline 1 Alta concentração da propriedade. \\
\hline $\begin{array}{l}\text { 2 Preponderam o controle familiar, o compartilhado (poucos controladores) e grupos } \\
\text { multinacionais. }\end{array}$ \\
\hline 3 Interesses dos minoritários ainda não inteiramente reconhecidos. \\
\hline 4 Minoritários poucos ativos. \\
\hline \multicolumn{1}{c|}{ Conselho Propriedade-gestão } \\
\hline 1 Alta sobreposição. \\
\hline 1 Estruturas informais e processos não definidos. \\
\hline 2 Maioria de conselheiros internos. Baixa demanda por externos. \\
\hline 3 Pouca clareza na divisão de papéis, conselho-direção, especialmente nas empresas \\
familiares. \\
\hline 4 Boas informações nos relatórios, mas insuficientemente analisadas. \\
\hline 5 Escassez de profissionais capacitados para atuação como conselheiros. \\
\hline 6 Envolvimento em questões estratégicas e operacionais. \\
\hline 7 Remuneração como fator pouco importante. \\
\hline
\end{tabular}

Fonte: ANDRADE e ROSSETTI, 2004 apud SILVA, Edson Cordeiro da. Governança corporativa nas empresas. São Paulo: Atlas, 2006. p. 135. Tabela 3.

${ }^{31}$ Trata respectivamente, da criação de mecanismos de controles internos de todos os seus processos e da criação do comitê de auditoria.

32 ANDRADE; ROSSETTI, 2004 apud SILVA, Edson Cordeiro da. Governança corporativa nas empresas. São Paulo: Atlas, 2006. p. 134-135. 


\section{Tendências do modelo Emergente de Governança Corporativa}

\begin{tabular}{|l|}
\multicolumn{1}{|c|}{ Modelo Emergente } \\
\hline \multicolumn{1}{|c|}{ Estrutura de Propriedade } \\
\hline 1 Alta concentração da propriedade. \\
\hline $\begin{array}{l}2 \text { Empresas fundamentalmente de controle familiar, consórcios resultantes de fusões, } \\
\text { maior presença de grupos de atuação global. }\end{array}$ \\
\hline 3 Mais explícita consideração pelos interesses dos não-controladores e minoritários. \\
\hline 4 Acionistas minoritários mais ativos, especialmente nos casos de mudanças de controle. \\
\hline \multicolumn{1}{|c|}{ Relação Propriedade-gestão } \\
\hline 1 Sobreposição moderada. \\
\hline 1 Estruturas formais. \\
\hline 2 Balanço entre conselheiros externos e internos. \\
\hline $\begin{array}{l}\text { } 3 \text { Conselheiros com boa capacitação, buscando formação especializada para atuação em } \\
\text { conselhos. }\end{array}$ \\
\hline 4 Maior clareza na divisão de papéis proprietários-conselho-direção. \\
\hline 5 Envolvimento centrado em questões estratégicas. \\
\hline 6 Maior efetividade. Decisões eficientes. \\
\hline 7 Remuneração variável mais estendida. \\
\hline
\end{tabular}

Fonte: ANDRADE; ROSSETTI, 2004 apud SILVA, Edson Cordeiro da. Governança corporativa nas empresas. São Paulo: Atlas, 2006. p.135. Tabela 4.

\section{Tendências do modelo de Mercado de Governança Corporativa}

\begin{tabular}{|l|}
\hline \multicolumn{1}{|c|}{ Modelo de Mercado } \\
\hline \multicolumn{1}{|c|}{ Estrutura de Propriedade } \\
\hline 1 Maior dispersão do controle e da propriedade. \\
\hline 2 Retenção de controle determinada pelo desempenho. \\
\hline 3 Consideração sistemática dos interesses dos acionistas minoritários. \\
\hline 4 Acionistas minoritários organizados e muito ativos. \\
\hline Relação Propriedade-gestão \\
\hline 1 Baixa sobreposição. \\
\hline Conselho de Administração \\
\hline 1 Estrutura completamente formal. \\
\hline
\end{tabular}




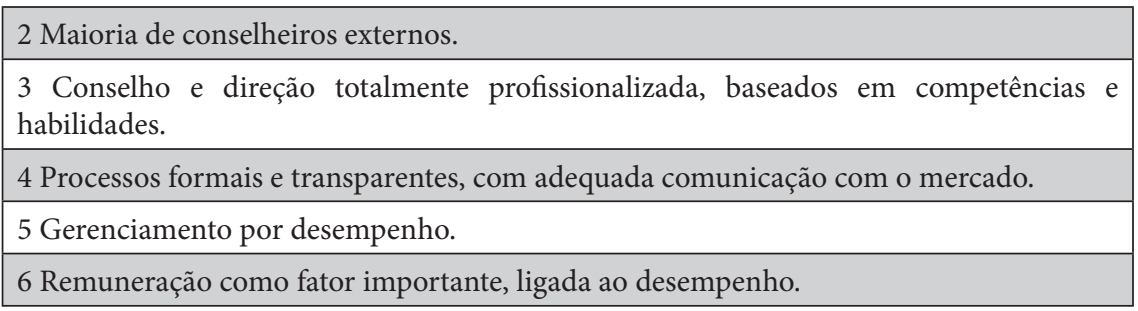

Fonte: ANDRADE; ROSSETTI, 2004 apud SILVA, Edson Cordeiro da. Governança corporativa nas empresas. São Paulo: Atlas, 2006. p.135. Tabela 5.

Nesse contexto, é visível a mudança gradual das empresas em incorporar e uniformizar práticas de transparência e gestão ética, tornando progressiva a transformação do mundo empresarial sob a ótica da governança corporativa.

Enfim, existem consistentes evidências de que o Brasil tende a aperfeiçoar cada vez mais, não apenas no mercado de capitais e nas suas estruturas empresariais, mas como também na gestão responsável e perene em prol do desenvolvimento econômico, social e ambiental, de modo transparente e eqüitativo, envolvendo nesse processo todos os stakeholders internos e externos.

\subsection{Aspectos principais da Sarbanes-Oxley Act: uma análise comparativa com a legislação societária brasileira}

A criação da Sarbanes-Oxley Act se fez necessária diante das inobservâncias das prerrogativas de boa gestão corporativa por parte das empresas, principalmente das norte-americanas, que provocaram a redução do nível de confiança dos investidores, afetando os custos de capital e a geração de fluxo financeiro, fatores estes, primordiais para o crescimento das corporações.

A lei confrontou as práticas lesivas que expunham as sociedades anônimas a elevados níveis de risco, documentações irregulares, fraudes de toda sorte que, por muitas vezes, afetavam profundamente o mercado e alimentavam a queda das Bolsas de Valores. 
Ao mesmo tempo, beneficiaram-se com fornecimento de maior confiabilidade ao investidor e sustentabilidade, vez que as responsabilidades positivadas pela lei não ficam somente no âmbito profissional dos administradores, codificam também a responsabilidade pessoal dos auditores, dos diretores e dos consultores.

Dessa maneira, ficam os agentes sujeitos às penas dessa lei que, dependendo do caso concreto, variam de 10 a 20 anos de prisão e multa de US\$ 5 milhões, abarcando tanto as empresas estrangeiras quanto as nacionais que atuam no mercado de capitais norte-americanos.

Várias regras da Sarbanes-Oxley Act já foram instituídas no Brasil pela Comissão de Valores Mobiliários e pela Lei 10.303/01 sobre as questões societárias, estabelecendo a responsabilidade pela elaboração dos balanços que devem ser assinados pelos administradores das empresas.

Após promulgação da nova Lei das S.A. (Sociedade Anônima) brasileira, em parte, adequada com o intuito de atender a Sarbanes-Oxley Act para as empresas nacionais com capital transacionável na Bolsa americana, não se encontraram grandes dificuldades para enquadrá-la em suas práticas organizacionais nacionais.

A exceção ficou por conta da determinação da Lei Sarbanes-Oxley, no que tange às companhias possuírem Comitê de Auditoria para seus relatórios anuais e à Legislação Societária brasileira, não há a existência dessa figura e sim,ConselhoFiscal. Após o conhecimento sobre a Legislação Societária no Brasil, a SEC ${ }^{33}$ (Securities and Exchange Commission), órgão regulador dos mercados de capitais norte-americanos, aceitou a utilização do Conselho Fiscal como substituição do Comitê de Auditoria.

De acordo com a tabela abaixo, pode-se observar de maneira simplificada as empresas brasileiras que optaram pelo Comitê de Auditoria ou por um modelo similar, no caso, o Conselho Fiscal.

\footnotetext{
${ }^{33}$ A SEC aboliu a constituição do Comitê de Auditoria para os países que possuem na legislação a obrigatoriedade da constituição do Conselho Fiscal, que é o caso do Brasil; prerrogativa válida apenas para empresas estrangeiras.
} 


\section{Quadro comparativo entre as empresas nacionais que optaram pelos sistemas: Comitê de Auditoria ou regime similar}

\begin{tabular}{|l|l|}
\hline \multicolumn{1}{|c|}{ Comitê de Auditoria } & \multicolumn{1}{c|}{ Conselho Fiscal adaptado } \\
\hline Aracruz Celulose & Ambev \\
\hline Banco Itaú & Braskem \\
\hline Bradesco & Cemig \\
\hline Copel & CPFL \\
\hline Gol Linhas Aéreas & Embratel \\
\hline Pão de Açúcar & Embraer \\
\hline Petrobrás & Gerdau \\
\hline Sabesp & Net Serviços \\
\hline Sadia & Perdigão \\
\hline Telesp & Tele Norte leste celular \\
\hline Telesp Celular Participações & Telemig celular \\
\hline Tele Sudeste Celular participações & Tim participações \\
\hline Tele Centro-oeste & Vale \\
\hline Tele leste celular participações & Ultrapar \\
\hline Unibanco & Votorantin \\
\hline
\end{tabular}

Fonte: BARCELLOS, Revista Capital Aberto, Especial SOX, 2005. Tabela 6

Como principais alterações introduzidas pela Lei Societária Nacional (Lei 10.303/01) e a iniciativa da Bolsa de Valores Mobiliários, no intuito de criar novos mercados, contemplaram-se diversas regras de governança corporativa nascidas dos princípios do disclosure, compliance e accountality, com o objetivo de facilitar o processo de privatização e de maximizar o valor recebido pela União, ao impedir a extensão aos minoritários dos grandes ágios pagos nos leilões.

Outra mudança bastante significativa diz respeito à Lei 11.638/07, em vigor desde janeiro de 2008, que alterou e revogou dispositivos da lei das sociedades por ações nacionais no tocante ao capítulo XV que versa sobre matéria contábil, objetivando possibilitar o processo de convergência das práticas adotadas no Brasil em conformidade com as normas de contabilidade do International Financial Reporting Standards (IFRS), estabelecendo até 2010 para as empresas estrangeiras quanto à sua adequação. 
A Reforma da lei das sociedades por ações, através do Decreto n. 3.995/01, e outros, propiciou diversas modificações na Lei n. 6.385/76 (Mercado de Valores Mobiliários), mas, em específico, no que diz respeito à estrutura da Comissão de Valores Mobiliários (CVM), com o intuito de conferir ao órgão regulador maior autonomia para exercer poder de polícia no mercado de capitais.

Nesse sentido, a CVM ampliou seus poderes na regulamentação e fiscalização do mercado financeiro, assumindo funções que até então eram prerrogativas do Banco Central, bem como eliminando as zonas cinzentas no que concerne às atribuições para os respectivos órgãos.

Dentre as principais inovações da Reforma destacam-se:

- A proporção entre ações ordinárias e preferenciais passa a ser de 50\% para as companhias constituídas a partir da nova lei.

- Modificação de vantagens atribuídas às ações preferenciais, visando fazer delas um produto mais atraente para o investidor.

- Os ordinaristas que representem no mínimo $15 \%$ do capital votante da companhia aberta e os prefencialistas que representem no mínimo $10 \%$ do capital total terão direito, cada qual, a eleger e a poder destituir, por votação separada, um membro do conselho de administração, desde que comprovem titularidade ininterrupta por três meses de sua participação acionária.

- Possibilidade de estatutos sociais indicarem arbitragem como forma de solução dos conflitos entre a companhia e seus acionistas ou entre minoritários e controladores.

- Novo conceito de valor mobiliário, que passa a incluir novos instrumentos, sempre atentando para a natureza de apelo à poupança popular que através deles possa se buscar.

- A CVM passa a ter natureza de entidade autárquica em regime especial, com personalidade jurídica e patrimônios próprios; gozará de autonomia financeira, orçamentária e política, esta última, garantida pela estabilidade de seus dirigentes, não estará subordinada hierarquicamente a qualquer outro órgão, embora esteja vinculada ao Ministério da Fazenda, e terá assegurada sua condição de autoridade administrativa independente, descabendo recurso na esfera administrativa de suas decisões, exceto no caso dos procedimentos sancionadores, nos quais cabe recurso ao Conselho de Recursos do Sistema Financeiro Nacional. 
- Tipificação de crime contra o mercado de capitais como manipulação de mercado, uso indevido de informação privilegiada e exercício irregular de cargo, profissão, atividade ou função.

Os principais impactos da Sarbanes-Oxley Act no órgão regulador de mercados de capitais (SEC) foram os seguintes:

- A criação do PCAOB - Public Company Accounting Oversight Board - é uma comissão supervisionada pela SEC que, em conjunto com representantes do setor privado, irá fiscalizar as auditorias independentes para que cumpram as premissas do ato, regulando as atividades dos profissionais que prestam serviços advocatícios e departamentos jurídicos das empresas norte-americanas e suas sucursais, (provavelmente a regra deverá atingir advogados estrangeiros), quais sejam:

- Conduzir qualquer atividade perante a SEC;

- Emitir opinião sobre a legislação americana de valores mobiliários ou as regras da SEC, em relação a documento que o advogado saiba que será remetido a ela; e

Aconselhar as sociedades emissoras de valores a respeito da necessidade de submeter qualquer documento ou informação ao SEC.

- A edição de regulamentos que estabeleçam padrões mínimos de conduta profissional para os advogados das empresas, isto é, pelo artigo 307, ficam estabelecidos padrões de conduta profissional para essa categoria de profissionais.

- A criação de uma regulamentação específica para reduzir os conflitos de interesses no trabalho de analistas e mercado.

- O desafio de conciliar a Sarbanes-Oxley Act com os interesses e as jurisdições dos países estrangeiros.

Os principais artigos da Sarbanes-Oxley Act que impactaram as empresas nacionais no que tange às adequações do Act são:

- Artigo 301: Regras adotadas pela SEC em relação ao Comitê de Auditoria independente, sendo que as principais são:

- Assessorar o Conselho de Administração; 
- Acompanhar e avaliar as atividades exercidas pela auditoria interna e independente;

- Facilitar e aperfeiçoar a comunicação entre os administradores e a auditoria independente; $\mathrm{e}$

- Acompanhar o processo de elaboração das demonstrações contábeis e de aprimoramento dos sistemas de controle interno.

No entanto, o Brasil solicitou à SEC que fossem levadas em consideração algumas especificações da legislação local, como mencionado anteriormente, sobre a substituição do Comitê de Auditoria pelo Conselho Fiscal, figura existente na Legislação Societária brasileira.

- Artigos 302 e 906: Certificações pelo CEO (Chief Executive Officer) e CFO (Chief Financial Officer) dos relatórios anuais, contendo as demonstrações financeiras das companhias sob pena de responsabilidade civil e criminal. Deverão assim, certificar as informações pertinentes aos controles internos das empresas, com vistas a garantir que as informações divulgadas representem de fato e de direito a real situação patrimonial e financeira, como instrumento primordial no disclosure das informações e na obediência às regras.

Para a certificação dessas informações, os administradores deverão atestar que:

- A companhia possui controles sobre as informações divulgadas e que eles são eficazes e, dessa maneira, possam garantir que as informações relevantes foram conhecidas de maneira exata e objetiva;

- Os controles internos e os procedimentos para a elaboração dos relatórios periódicos da companhia são suficientes para garantir a lisura das informações apresentadas;

- Divulgaram aos auditores internos, aos auditores independentes e ao Comitê de Auditoria as deficiências consideradas significativas e, ainda, os atos de possíveis fraudes detectados ou constatados;

- Informaram mudanças significativas ocorridas nos controles internos e na avaliação da efetividade dos controles de divulgação;

- As demonstrações financeiras refletem todos os ajustes materiais propostos pelos auditores independentes; e 
As transações, acordos e obrigações relevantes tenham sido informados, embora não registradas contabilmente no balanço.

Todos esses requisitos demonstrados acima não são obrigatórios segundo a Legislação Societária brasileira, mas de qualquer maneira, a transparência na divulgação de informações relevantes são práticas usuais de mercado.

- Artigo 304: Penalidades para diretores e conselheiros por violações do dever de conduta, quando eles modificarem e publicarem relatórios com alterações fraudulentas nas informações financeiras. Sob esse aspecto, o presente estudo já comentou as implicações desses atos, tanto sobre a responsabilidade penal como sobre a civil que recai não só na pessoa do profissional como também, na sua vida pessoal.

Sobre esse aspecto de responsabilização, a Lei Societária brasileira se coaduna com a SOX; não há, portanto, nenhuma divergência.

- Artigo 402: Proibição de empréstimos para conselheiros e diretores. Segundo a SOX, tornou-se ilegal, exceto pelas situações específicas e previstas na própria lei, a concessão, renovação ou prorrogação, direta ou indiretamente, por qualquer companhia emissora de ações, de empréstimos pessoais a administradores, conselheiros ou funcionários equiparados a administradores. Em análise comparativa entre a legislação norte americana e a brasileira, não há restrições específicas à concessão de empréstimos a administradores, desde que não haja conflito de interesses da companhia e, ainda, que sejam concedidos em condições igualitárias aos demais interessados na Sociedade.

- Artigos 404, 406 usque 409: Maior publicidade das informações e fiscalização pela SEC, que deverão ser publicadas em tempo real. Deverá o auditor independente certificar o relatório da administração sobre eficiência dos controles internos e dos procedimentos executados para a emissão dele. Restringe o Act à possibilidade de prestação simultânea de serviços de consultoria e assessoria pelos auditores contratados, já que isso, na maioria das vezes, acarreta "conflitos de interesses” por ocasião da necessária certificação, prejudicando uma avaliação idônea e isenta.

Muitas empresas nacionais já se adequaram aos aspectos da Sarbanes-Oxley Act, mas, o importante é que o mercado global tenha consciência que a implantação e adequação dessa Lei não poderão evitar novas fraudes, mas, com certeza, proporcionarão um início de reeducação baseadas na ética e na transparência das informações principalmente com o auxílio da tecnologia da informação crescente nessa nova era globalizada. 


\section{As empresas brasileiras operantes nas bolsas de valores norte- americanas e suas certificações na SOX}

Diferentemente do que ocorreu nos Estados Unidos, com o advento da Lei Sarbanes-Oxley em 2002, que exigiu melhores práticas de governança sob o império de uma força regulatória altamente punitiva no âmbito penal e civil, no Brasil, a governança corporativa tornou-se uma necessidade e uma iniciativa do próprio mercado que adotam as melhores práticas de gestão e profissionalização, como também tentam adequar-se às exigências desse Act por ser uma tendência internacional para conquista de mercados mundiais e zelar pelo bom nome empresarial.

Atualmente, é muito difícil uma empresa ter sucesso em oferecer suas ações ou outras formas de títulos mobiliários ao mercado de capitais, ou mesmo obter financiamentos com taxas de juros reduzidas e investimentos de uma instituição financeira, sem demonstrar a sua aderência e aplicação a um mínimo de boas práticas de governança corporativa que se sustentam nos pilares da eqüidade, da prestação de contas (accontability), da transparência (disclosure) e da responsabilidade corporativa (compliance).

Apesar de ser uma tendência internacional a adequação às normas da SOX, um número significativo de empresas brasileiras não está enquadrado nos Níveis Diferenciados de governança corporativa da BOVESPA (Nível, I, II e Novo Mercado $)^{34}$, sendo esses pontos culminantes para as companhias, com vistas a proporcionar um ambiente de negociação que estimule ao mesmo tempo o interesse dos investidores e a valorização das mesmas.

Assim temos no gráfico abaixo a classificação das empresas participantes nos níveis diferenciados de governança corporativa da BOVESPA.

\footnotetext{
${ }^{34}$ Com o objetivo de reanimar o mercado, a BOVESPA cria o novo mercado como segmento especial de listagem de ações de companhias que se comprometem voluntariamente a adotar as boas práticas de governança corporativa. Assim, são criados dois estágios intermediários: Níveis I e II que, juntamente com o novo mercado, estabelecem compromissos crescentes de adoção de melhores práticas de governança. As companhias de Nível I se comprometem principalmente com as melhorias na prestação de informações ao mercado e com a dispersão acionária. As companhias de Nível II, além da aceitação das obrigações contidas no Nível I, as empresas e seus controladores adotam amplas práticas de governança e de direitos adicionais para os acionistas minoritários.
} 


\section{Quadro das empresas nacionais participantes nos níveis diferencia- dos de governança - BOVESPA}

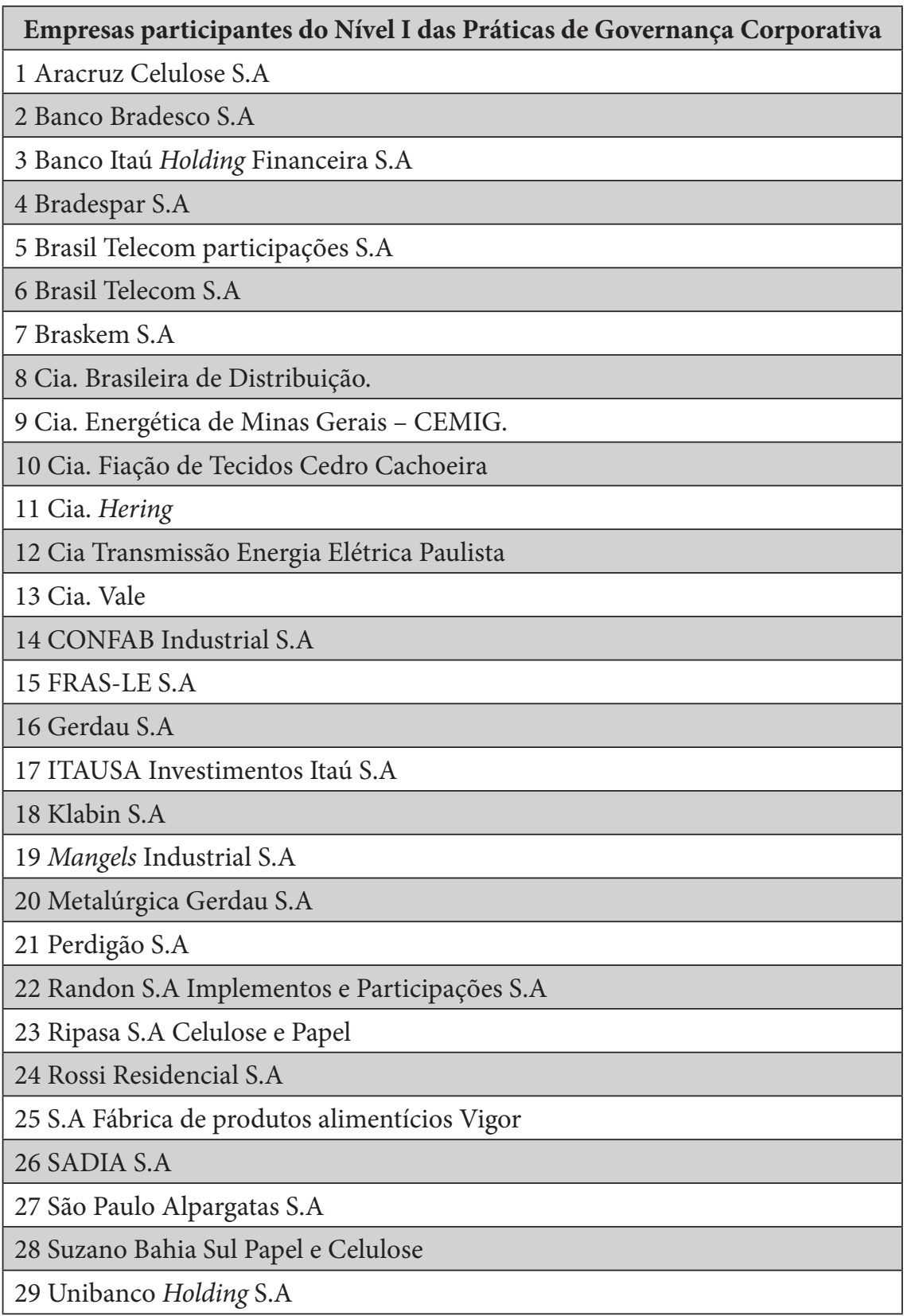




\begin{tabular}{|l|}
\hline 22 Randon S.A Implementos e Participações \\
\hline 23 Ripasa S.A Celulose e Papel \\
\hline 32 Votorantim Celulose e Papel S.A \\
\hline 33 WEG S.A \\
\hline Empresas participantes do Nível II das Práticas de Governança Corporativa \\
\hline 1 All América Latina Logística S.A \\
\hline 2 Centrais Elétricas de Santa Catarina S.A \\
\hline 3 Eletropaulo Metrop. Elet. De São Paulo S.A \\
\hline 4 Eternit S.A \\
\hline 5 Gol Linhas Aéreas Inteligentes S.A \\
\hline 6 Marcopolo S.A \\
\hline 7 Net Serviços de Comunicação S.A \\
\hline 8 Suzano Petroquímica S.A \\
\hline 9 TAM Linhas Aéreas \\
\hline \multicolumn{1}{|c|}{ Empresas participantes do Novo Mercado das Práticas de Governança } \\
\hline 1 Cia Concessões Rodoviárias S.A \\
\hline 2 Cia Saneamento Básico do Estado de São Paulo S.A \\
\hline 3 CPFL Energia S.A \\
\hline 4 Diagnósticos da América S.A \\
\hline 5 Grandene S.A \\
\hline 6 Natura Cosméticos S.A \\
\hline 7 Porto Seguro S.A \\
\hline 8 Renar Macas S.A \\
\hline 9 Submarino \\
\hline 10 Localiza \\
\hline 11 Embraer \\
\hline 12 Gafisa \\
\hline 13 Perdigão \\
\hline
\end{tabular}


Atualmente, 33 empresas brasileiras possuem ações ou títulos negociados nas bolsas norte-americanas NYSE (Bolsa de Valores de Nova Yorque) e Nasdaq (National Association of Securities Dealers Automated Quotations System) e que exigem o cumprimento às regras de divulgação da Securities and Exchange Comission (SEC). São elas:

\begin{tabular}{|l|l|l|l|l|}
\hline Ambev & CEMIG & Gerdau & Sadia & Telesp \\
\hline Aracruz & COPEL & Gol & TAM & Tim \\
\hline Bradesco & CPFL & Itaú & Tele N. L. Cel. & Ultrapar \\
\hline BR Telecom & CSN & NET & Tele N. Leste & Unibanco \\
\hline Braskem & CVRD & Perdigão & Telebrás & Vivo \\
\hline CBD & Embraer & Petrobrás & Telemig & VPC \\
\hline & Gafisa & Sabesp & Telepar & Vale \\
\hline
\end{tabular}

Fonte adaptada: $2^{\circ}$ Estudos sobre as melhores práticas de governança corporativa no Brasil e nos Estados Unidos, 2007, Base - Relatório Anual 20-F. Tabela 8.

Das 33 empresas mencionadas, 32 têm a obrigação de arquivar o Formulário $20-\mathrm{F}^{35}$ na SEC, pois foi permitida à Telebrás a isenção no seu arquivamento em razão do número reduzido de acionistas. Adicionalmente, a Gafisa entrou na lista somente em 2007 e, dessa forma, o formulário utilizado para a análise das informações foi o F-1 (Formulário utilizado para a abertura de capital).

Em 2005, a BOVESPA lançou dois importantes Índices de Governança Corporativa, sendo que o primeiro criado no final de junho denominado Índice Tag Along (ITAG) e o segundo em dezembro denominado Índice de Sustentabilidade Empresarial (ISE). O propósito do Tag Along é medir o comportamento das ações empresariais baseado no direito dos acionistas minoritários receberem o mesmo valor ou pelo menos um percentual pago ao controlador na oportunidade da mudança de controle.

Atentamos que o Índice Tag Along criado pela Bovespa constituiu-se de um referencial muito valioso para realmente enquadrar as empresas nas

\footnotetext{
${ }^{35}$ Conforme estabelecido pela Seção 404 da Lei Sarbanes-Oxley e pelas regras de implementação da SEC, as empresas estrangeiras devem arquivar a Certificação dos Controles Internos anualmente junto ao formulário $20-\mathrm{F}$.
} 
práticas da boa governança corporativas vez que, pela atual Lei Nacional das Sociedades por Ações, não há nenhum dispositivo referente ao percentual de Tag Along para as ações preferenciais. ${ }^{36}$

No que concerne aos sócios minoritários, somente se refere a ações ordinárias, estabelecendo que as empresas abertas ofereçam àqueles que possuem ações ordinárias pelo menos $80 \%$ do valor pago pelo controle.

Existentes no Brasil, algumas correntes que incentivam as empresas a pagarem além da determinação da Lei, as empresas pertencentes ao Nível II são obrigadas a fornecer o Tag Along de 100\% para as ações ordinárias e 70\% para as ações preferenciais, enquanto no Novo Mercado, imperando somente as empresas que possuem ações ordinárias, os acionistas recebem 100\% de Tag Along.

O Índice de Sustentabilidade Empresarial cuja metodologia foi de competência da Fundação Getúlio Vargas de São Paulo (FGV/SP), trata-se de um questionário ofertado para as empresas que desejam fazer parte do Índice baseado em 04 critérios de sustentabilidade: o social, o econômico-financeiro, o ambiental e a governança corporativa, este último como grupo específico.

As questões sociais, ambientais e econômico-financeiras estão divididas em quatro critérios: políticos (indicadores de comprometimento); gestão (indicam planos, programas, metas e monitoramento); desempenho (indicadores de performance); e cumprimento legal (avalia o quanto as empresas cumprem as legislações).

Quanto ao grupo específico sobre a governança corporativa, esse se divide em: propriedade, conselho, gestão, auditoria e fiscalização e conflitos de interesses. ${ }^{37}$

\footnotetext{
${ }^{36}$ As ações são títulos nominativos negociáveis, que representam para quem as possui uma fração do capital social de uma empresa, podendo ser ordinárias e preferenciais. As ações ordinárias concedem àqueles que as possuem o poder de voto nas assembléias deliberativas da companhia. As ações preferenciais oferecem preferência na distribuição de resultados ou no reembolso do capital, em caso de liquidação da companhia, não concedendo o direito de voto ou restringindo-o.

${ }^{37}$ SILVA, Edson Cordeiro da. Governança corporativa nas empresas. São Paulo: Atlas, 2006. p. 43-46.
} 
Muito embora timidamente, as empresas nacionais estejam adquirindo consciência sobre a importância da responsabilidade corporativa como alavancagem estratégica de seus negócios, muito ainda precisa ser feito para coibir práticas contrárias à transparência na gestão empresarial.

Esse fato necessita ser revisto como se pode observar na declaração da OECD (Organization for Economic Cooperation Development)) em seus Principles of Corporate Governance ${ }^{38}$, relatando que "o grau de observância dos princípios básicos da boa governança corporativa, por parte das empresas, é um fator cada vez mais importante nas decisões de investimentos”.

\section{Considerações finais}

Em junho de 2002, a Lei Sarbanes-Oxley criou novas regras para o mundo corporativo, exigindo maior transparência na divulgação dos relatórios contábeis pelas empresas para que atestem as reais posições financeiras e sua eficácia, sob pena de sanções draconianas para as companhias e seus administradores que desrespeitarem seus preceitos.

Os escândalos contábeis americanos, franceses, italianos e de outras nacionalidades, divulgados entre 2001-2005, fizeram com que houvesse uma repercussão mundial de modos distintos entre os países e empresas, mas todos direcionados a uma maior consciência sobre a importância de se produzirem mecanismos eficientes para assegurar que as ações praticadas pela administração empresarial estejam alinhadas com os direitos dos acionistas de maneira a minimizar as possíveis fraudes e extirpar os Conflitos de Agência.

As práticas de melhores gestões corporativas surgem, obrigatoriamente, para inserir as empresas às novas realidades mundiais que passam por profundas transformações. Essas transformações no mundo empresarial ultrapassam as fronteiras do social e cultural, atingindo a economia, a

\footnotetext{
${ }^{38}$ OECD (Organization for Economic Cooperation Develpment). Principles of Corporate Governance, 2004. Disponível em: <http:/www.oecd.org/dataoecd/32/18/31557724.pdf.> Acesso: maio 2008.
} 
política e a tecnologia de inovação no modo de como gerir os investimentos e a maneira de lidar com a competitividade no cenário internacional.

Mas, atualmente, com o liberalismo, com a formação dos blocos econômicos, com a desregulamentação como efeitos da globalização e com a transnacionalização da economia, não bastam às empresas focarem somente os lucros em competitividade para sua sobrevivência. Os efeitos da abertura da economia transpassam a cadeia de valores e se difundem por toda sociedade, alterando posturas e formas de conduta dos agentes públicos e privados, bem como o perfil dos profissionais atuantes no mercado.

Competitividade e globalização são conceitos que deverão ser compreendidos e analisados sob um enfoque multidisciplinar que abarque seus efeitos negativos e positivos no meio ambiente empresarial, social e econômico, não devendo ficar adstritos a aspectos meramente teóricos e abstratos e, sim, aliados às ciências jurídicas, econômicas, administrativas e sociais para melhor se mensurar a importância do assunto e seus aspectos contraditórios.

Com a governança corporativa, as empresas procuram a adoção de critérios e regras para organizarem e viabilizarem uma gestão mais transparente e equânime com vistas à redução de seus conflitos. Naturalmente, os conflitos são inerentes à natureza humana, e os interesses, em regra, são antagônicos, mas, ao praticar a governança corporativa, as empresas buscam alternativas para que os interesses sejam convergentes para uma boa gestão.

As empresas cada vez mais procurarão suas diferenciações no mercado mundial, as quais serão movidas por forças externas às organizações, muito além das fronteiras da governança corporativa implantadas no ambiente intramuros empresariais. Ganharão o mundo, com ética, transparência e equidade, requisitos que não só o mundo empresarial vem incessantemente buscando, mas todo o planeta. 
The Sarbanes-Oxley Act as ambient instrument of ethical values, social-economics and in the corporative governance: its impacts in Brazil

\title{
La Ley Sarbanes-Oxley como instrumento de los valores éticos, socioeconómicos y ambientales en la gobiernaza corporativa: sus impactos en el Brasil
}

\begin{abstract}
The present article has as objective to discourse on the impacts of the Law Sarbanes-Oxley in the enterprise spheres and its possible democratization in the markets leaving of analyses on the process of globalization and its unfolding in the attempt of consolidation of the movements and projects so that ways that the companies in a bigger support in the social-economics scopes lead, social and ambient, based are to establish in the principles of the corporative governance. The corporative governance is justified and defended, as much for the companies how much for the society and the State as phenomenon that accumulates of stocks the recognition of the necessity for the survival and perenity of a company in the international scene, through the use of practical of better management and professionalization. The market perceives the governance as instruments for the valuation of its investments and the companies in turn become more attractive before the investors from the awareness of the principles of transparency and equity. Currently the question of the corporative governance accumulates of stocks much more of what the justification of its creation based in the international corporative scandals encloses a bigger context for the companies who if worry in getting success ahead of the international markets to divulge its good name and to value its papers in the action market.
\end{abstract}

Keywords: Corporative governance. Globalization. Transparency. Equity. Market of action. 


\section{Referências}

BARBOSA, L. O centro do universo. Exame, São Paulo, ano 35, n. 7, p. 107-110, 2001.

BARCELLOS, Marta. Revista Capital Aberto, [S.1.] Especial SOX, 2005.

BERNA, Vilmar; URBAN, Teresa. Os heróis do verde. Época. São Paulo, Edição Especial, p. 51-57, out. 2006.

BORGERTH, Vânia Maria. SOX. Entendendo a Lei Sarbanes-Oxley. São Paulo: CENGAGE/Learning, 2007.

BOVESPA. [Home page]. Disponível em: <http://www.bovespa.com.br>. Acesso em: 19 maio 2008.

CASTELL, Manuel. O poder da identidade. São Paulo: Paz e Terra, 1999.

DANNEMANN, Fernando Kiyzinger. Leito de Procusto: expressões populares. Disponível: <www.fernandodannemann.recantodasletras.com.br/ visualizar. php?=135407>. Acesso em: 10 maio 2008.

DEJOURS, Christophe. A banalização da injustiça social. Rio de Janeiro: FGV, 2001.

ENRIQUEZ, E. Os desafios éticos nas organizações modernas. Revista de Administração de Empresas, São Paulo, v. 37, n. 2, p. 6, abr./jun. 1997.

FARIA, J. H.; MENEGHETTI, F. K. Discursos organizacionais. In: ENANPAD, 25., 2001, Campinas. Anais do XXV da Anpad. São Paulo: Anpad, 2001.

FREITAS, M. E. de. A questão do imaginário e a fronteira entre cultura organizacional e a psicanálise. In: MOTTA, F.C.P.; FREITAS, M. E. de. Vida psíquica e organização. São Paulo: FGV, 2000.

HAMILTON, S. The enron collapse. [S.1.]: Internacional Institute for Management Development, 2003.

IANNI, Octavio. A era do globalismo. 9. ed. Rio de Janeiro: Civilização Brasileira, 2007. p. 95.

INSTITUTO ETHOS. Responsabilidade social corporativa. Disponível em: <http:// www.ethos.org.br>. Acesso em: 10 maio 2008. 
INSTITUTO BRASILEIRO DE GOVERNANÇA CORPORATIVA (IBGC). Código das melhores práticas de governança corporativa. 2004. Disponível em: <http://www.ibgc.org. br>. Acesso em 10 maio 2008.

KAPLAN, Robert S.; KIRON, David. Accounting fraud at wordcom. [S.1], Harvard Business School, 2004.

KPMG. Audit Committe Institute. SOX 301. [S.1.]: Conselho Fiscal ou Comitê de Auditoria, 2005.

KUMPE, T.; BOLWIJN, P. T. Toward the innovative firm. Challenge for R\&D management. Research Technology Management, [S.1.], jan./fev. 1994.

MOREIRA, Igor. O processo de globalização e regionalização. Ciências e Letras, Porto Alegre, n. 19, p. 15, 1997.

OECD Principles of Corporate Governance, 2004. Disponível em: <http:/www.oecd.org/ dataoecd/32/18/31557724.pdf.> Acesso em: maio 2008.

ROSENAU, James; CZEMPIEL, Ernest-Otto. Governança sem governo: ordem e transformação na política mundial. Brasília: Universidade de Brasília, 2000.

SEC- SECURITIES EXCHANGE COMMISSION. Litigation releases. Disponível em: $<$ www.sec.gov/litigation>. Acesso em: 19 maio 2008.

SHLEIFER, Andrei; VISHNY, Robert. A survey of corporate governance. Journal of Finance, v. 52, n. 2, p. 737-738, 1997.

SILVA, Edson Cordeiro da. Governança corporativa nas empresas. São Paulo: Atlas, 2006.

SOARES, Gianna de Paula. Responsabilidade social corporativa: por uma boa causa? Revista Era Eletrônica: Fórum Estudos Críticos em Administração, São Paulo, p. 11, 2004.

WAKEMAN JR, Frederic E. Transnational and comparative research, social science research council. Annual Report, New York, 1988.

WARNER, J. Ethics for sale: in today's regulatiory climate, CEO's may have choice but to buy. Bunissess Publications, 2004. Disponível em: <http://findarticles.com/p/articles/ mi_m4070/is_203/ai_n8641866/2log=content;col1.> Acesso em: maio 2008. 